\title{
Diversity of endophytic fungal community associated to the roots of Argania spinosa (L.) Skeels growing in the arid and semi-arid regions of Algeria
}

\author{
Abdallah NOUI ${ }^{1,2,3}$, Abdelkader SAADI ${ }^{2}$, Abdul SHAKOOR ${ }^{4,5}$, Abdelaziz MEROUANE ${ }^{1,2}$, Nassima \\ MOSTEFA DELLA $^{1,2}$, Gul ZAIB ${ }^{6}$, Damilare Stephen AKINYEMI ${ }^{5,7,8}$, Housseyn MEDJAHED ${ }^{1}$
}

Received February 11, 2019; accepted September 06, 2019. Delo je prispelo 11. februarja 2019, sprejeto 06. septembra 2019.

Diversity of endophytic fungal community associated to the roots of Argania spinosa (L.) Skeels growing in the arid and semi-arid regions of Algeria

Abstract: Current study identified endophytic fungi associated to Argania spinosa (argan) roots and revealed diverse haplotype diversity by the sequencing of internal transcribed spacer (ITS). 586 operational taxonomic units were identified and these operational taxonomic units (OTUs) could be assigned to fungal functional diversity such as endophytes, ectomycorrhiza and putative pathogens. Ascomycota phylum was abundant. Beside Ascomycota phylum, Basidiomycota members were also found in argan roots. Geopora, Sebacina, Knufia, Tomentella, Penicillim had high relative abundance. Our results highlighted a non-nested assemblage of fungi. Current nonnested findings also confirm that fungi have similar pattern found in other habitats. Pairwise analysis mirrored segregation pattern between same and different functional fungal group. Fungi in semi-arid conditions are non-randomly structured. Members of Ascomycota phylum had high Z-scores. This is the first molecular study conducted in arid and semi-arid habitats of Algeria aiming to identify fungi associated with roots in argan tree. Given the fact that deserts are among harsh environments and fungi associated to desert plants may have implications for biodiversity and ecosystem functioning.

Key words: Argania spinose; fungi, diversity; internal transcribed spacer; endophytes; ectomycorrhiza
Raznolikost endofitskih glivnih združb povezanih s koreninami argana (Argania spinosa (L.) Skeels), v sušnih in polsušnih območjih Alžirije

Izvleček: Namen raziskave je bil določiti endofitske glive, ki so povezane s koreninami argana (Argania spinosa) in odkriti raznolikost različnih haplotipov s sekvenciranjem ITS DNK. Določenih je bilo 586 operacijskih taksonomskih enot in te enote (Operational Taxonomic Unit, OTUs) lahko pripišemo funkcionalni raznolikosti gliv kot so endofiti, ektomikorizne glive in potencialni patogeni. V koreninah argana so bili najbolj pogosti predstavniki zaprtotrosnic (Ascomycota), poleg njih so bili najdeni tudi predstavniki prostotrosnic (Basidiomycota). Rodovi Geopora, Sebacina, Knufia, Tomentella, Penicillim so imeli veliko relativno pogostnost. Rezultati raziskave so osvetlili nepovezanost skupin gliv. Podobni vzorci nepovezanih skupin gliv so bili najdeni tudi v drugih habitatih. Analiza parov je pokaza vzorce segregacije med enakimi in različnimi funkcionalnimi skupinami gliv. Glive polsušnih območij niso naključno organizirane. Predstavniki zaprtotrosnic imajo velikokrat normalno porazdelitev. To je prva molekularna raziskava v sušnih in polsušnih habitatih Alžirije, katere namen je bil določiti glive, ki so povezane s koreninami argana. Puščave so med najbol ekstremnimi okolji in glive, ki so povezane s puščavskimi rastlinami so pomemben del raznolikosti in delovanja teh ekosistemov.

Ključne besede: Argania spinose; glive; raznolikost; ITS; endofiti; ektomikoriza

1 Hassiba Benbouali University of Chlef, Laboratory on Natural bio resources, Algeria

2 Hassiba Benbouali University of Chlef, Faculty of Nature and life sciences, Algeria

3 Corresponding author, e-mail: a.noui@univ-chlef.dz

4 Institute of Botany Chinese, State Key Laboratory of Vegetation and Environmental Change

5 Henan University, Key laboratory of Geospatial Technology for the Middle and Lower Yellow River Regions, China

6 Yangzhou University, Institute of Epigenetics and Epigenomics, China

7 University of Chinese Academy of Sciences

8 Yangzhou University, Institute of Epigenetics and Epigenomics, China 


\section{INTRODUCTION}

Fungi are important component of ecosystem and play pivotal role in ecosystem functioning such as carbon and nutrient cycling (Courty et al., 2010; Treseder, 2004). Among fungi there are diverse functional groups such as mycorrhizal, endophytic and pathogenic fungi. These fungi interact with diverse plant species (Smith \& Read, 2008), and such interactions are vital for survival and growth of plant species (Finlay, 2008).

Among harsh ecosystem, desert ecosystems represent one of the challenging habitats for microorganism, as water affects microbial activity, which in turn could play crucial role in ecosystem functioning (Austin et al., 2004; Collins et al., 2008). Argan tree (Argania spinosa (L.) Skeels) is a slow growing endemic plant species in distributed in north-west Africa (Díaz-Barradas et al., 2010). This tree species is known for its ecological importance because it creates a favourable microclimate for the development of other plant species and protects soils against erosion. In addition, it plays a socio-economic role in the regions where it grows. Each part of the plant including leaves and fruits are used as source of forage for cattle, whereas timber is widely used for fuel purpose, furthermore argan oils have therapeutic properties to cure scars and serve as an anti-ageing agent (Charrouf \& Guillaume, 2009). In Algeria, there is decline in population of argan plant due to ecological and anthropogenic factors including climate change and grazing pressure (Charrouf \& Guillaume, 2009; Díaz-Barradas et al., 2010).

Given the drastic effect of climate change and anthropogenic factors, it is important to explore the fungal community of desert plant species, such as argan tree. This plant has strong and deep root system (Kenny \& De Zborowski, 2007), which harbours high fungal diversity (Sellal, 2016). Previous focus had been paid to study fungal endophytes in arid and semi-arid habitats. For instance, revealed high colonization of fungal endophytes in semi-arid. Martínez-García et al. (2011) also highlighted impact of shrubs on root associated fungi and highlighted importance of selective pressure in determining root associated fungi.

To our knowledge fungal diversity in arid and semiarid is rarely explored and understood owing to correct identification and most of the fungal strains are noncultivable in laboratory conditions and laboratory based culturing method may not capture the real fungal diversity (Zhang et al., 2016). Nonetheless, a development in a high throughput sequencing technology provides an excellent platform to explore below ground functional fungal diversity (Buee et al., 2009; Fortuna Miguel et al., 2010).

Nestedness or species-species interaction networks describing the interactions between species is important structural ecological property, and nestedness has revealed positive influence on diversity against catastrophic effect. Nestedness has been proposed to assess community assembly which can further push our understanding about community structure and interactions therein (Ulrich et al., 2009).

We hypothesize fungal community may lack nestedness pattern but could show other non-random pattern such as segregation and aggregation. We propose that limited resources, such as water paucity and nutrients availability generate the segregation pattern.

Key objectives of current study were to: I) identify root associated functional endophytic fungal diversity; II) assess how different fungal taxonomic genera are organize in roots? III) find potential fungal OTUs segregation and aggregation pattern.

\section{MATERIAL AND METHODS}

\subsection{STUDY AREAS AND SAMPLING}

The study was carried out in three different climatic regions of Algeria: Tindouf, Mostaganem and Chlef. The area of Tindouf is a desert region in the south-west of Algeria $\left(28^{\circ} 29^{\prime} 56.47^{\prime \prime} \mathrm{N} \quad 8^{\circ} 07^{\prime} 09.72^{\prime \prime} \mathrm{W}\right)$. Mostaganem $\left(35^{\circ} 48^{\prime} 09.81^{\prime \prime} \mathrm{N} 0^{\circ} 03^{\prime} 59.30^{\prime \prime} \mathrm{E}\right)$ and Chlef $\left(36^{\circ} 09^{\prime} 46.95^{\prime \prime} \mathrm{N}\right.$ $\left.1^{\circ} 20^{\prime} 12.22^{\prime \prime} \mathrm{E}\right)$ are situated in the north-west of Algeria (Table1)

At each region, five healthy specimens $(20-30 \mathrm{~m}$ apart) of Argania spinosa were randomly selected. Four replications in cardinal directions of each tree were collected and homogenised to form a single sample in cardinal directions. In each direction the top litter $(20-40 \mathrm{~cm})$ was removed to eliminate part of the dry/not decomposed leaf litter, and samples (soils and argan roots) were collected at $0-30 \mathrm{~cm}$ depth and pooled. Fine roots were excavated and traced from the originating tree to ensure identity. Samples were kept in plastic bags and stored at $4{ }^{\circ} \mathrm{C}$ until processing.

\subsection{DNA EXTRACTION FROM ROOTS AND PCR}

After roots surface sterilization by soaking in $70 \%$ ethanol (7:3, v/v, $1 \mathrm{~min}), 3 \%$ sodium hypochlorite ( $3 \mathrm{~min})$ and $70 \%$ ethanol (7:3, v/v, $1 \mathrm{~min}$ ) and were then rinsed twice for $1 \mathrm{~min}$ in sterile water, genomic DNA was extracted from field roots, using the genomic DNA Kit (Nucleo Spin Soil). The manufacturer's protocol was modified in that $250 \mathrm{mg}$ of roots was ground by hand 
Table 1: Sites characteristics

\begin{tabular}{llll}
\hline Location & Chlef & Mostaganem & Tindouf \\
\hline Coordinates & $36^{\circ} 09^{\prime} 46.95^{\prime \prime}{\mathrm{N} 1^{\circ} 20^{\prime} 12.22^{\prime \prime} \mathrm{E}}^{\circ} 35^{\circ} 48^{\prime} 09.81^{\prime} \mathrm{N} \mathrm{0} 03^{\prime} 59.30^{\prime \prime} \mathrm{E}$ & $28^{\circ} 29^{\prime} 56.47^{\prime \prime} \mathrm{N} 8^{\circ} 07^{\prime} 09.72^{\prime \prime} \mathrm{W}$ \\
Mean annual temperature & $18.6^{\circ} \mathrm{C}$ & $18.3^{\circ} \mathrm{C}$ & $23.4^{\circ} \mathrm{C}$ \\
Mean annual precipitation & $394 \mathrm{~mm}$ & $436 \mathrm{~mm}$ & $30 \mathrm{~mm}$ \\
Altitude & $119 \mathrm{~m}$ & $35 \mathrm{~m}$ & $537 \mathrm{~m}$
\end{tabular}

Acacia tortilis Forssk. Acacia raddiana Forssk.

Anabasis articulata Forssk., Asphodelus sp.

Aristida pungens Desf., Calotropis procera Aiton

Sonchus arvensis L.

Malva sylvestris L.

Avena sativa L.

Echium vulgare L.

Associated plants

Oxalis $\mathrm{sp}$

Olea europea L.
Hordeum vulgare L.

Bromus sp.

Plantago laceolata L.

Antenis coatula $\mathrm{L}$.

Chrysanthemum sp.

Cenaurea napifolia L.
Chrysocomoides cassini Desf.

Euphorbia guyoniana Boiss. \& Reut. Faidherbia albida Delile, Genista saharae Coss. \& Durieu

Helianthemum lippii L.

Moricandia arvensis L.,

Marrubium deserti Noë

Nolletia. Retama monosperma L.

Rhus tripartitus L., Zizyphus lotus Lam., Zilla spinosa L. with pestle in a mortar containing $700 \mu \mathrm{l}$ of lysis solution before transfer to Eppendorf tube and incubated at $70{ }^{\circ} \mathrm{C}$ for $10 \mathrm{~min}$. To study the effect of DNA dilution on PCR inhibitors, after extraction, DNA was diluted $1: 1,1: 10,1: 20$ and 1:100 with ultra-pure water, in order to obtain DNA containing less PCR inhibitors. Fungal sequences were amplified using the primers ITS1F-ITS4 (White et al., 1990) to target a complete rDNA ITS region. The PCRs were carried out in a final volume of 25 $\mu \mathrm{l}$, containing $12.5 \mu \mathrm{l}$ PPP Master Mix (Top-Bio, Prague, Czech Republic) $1 \mu \mathrm{l}$ of each primer solution $(10 \mu \mathrm{M}), 1$ $\mu \mathrm{l}$ of DNA template and $9.5 \mu$ l ultra-pure water. The PCR conditions were as follow: initial denaturation at $94{ }^{\circ} \mathrm{C}$ for $4 \mathrm{~min}$, followed by 35 cycles of denaturation at $94^{\circ} \mathrm{C}$ for $45 \mathrm{~s}$, annealing at $52^{\circ} \mathrm{C}$ for $45 \mathrm{~s}$ and extension at $72^{\circ} \mathrm{C}$ for $1 \mathrm{~min} 30 \mathrm{~s}$, with a final extension at $72^{\circ} \mathrm{C}$ for $10 \mathrm{~min}$. All PCR reactions were run in Eppendorf PCR cycler. PCR products were examined on a $1 \%(\mathrm{w}: \mathrm{v})$ agarose gel with an ethidium bromide staining in and compared to a 100 bp DNA ladder. PCR products (only DNA diluted $1: 20$ and $1: 100$ were used in this step) were purified using QIAquick $^{\circledast}$ PCR purification Kit (Qiagen).

\subsection{NESTED PCR}

The products of the first PCR were diluted 1:1000 with ultra-pure water and used as template DNA for the second PCR amplification using various combinations between gITS7 (Ihrmark et al., 2012) and ITS4 (White et al., 1990) including Illumina adapters. Each PCR reactions $(25 \mu \mathrm{l})$ contained 12,5 $\mu$ PPP Master Mix (Top-Bio, Prague, Czech Republic) $0.5 \mu$ of each primer solution $(10 \mu \mathrm{M}), 1 \mu \mathrm{l}$ of DNA template and $10.5 \mu \mathrm{l}$ ultra-pure water with the following cyclin conditions: initial denaturation at $94{ }^{\circ} \mathrm{C}$ for $4 \mathrm{~min}$, followed by 25 cycles of denaturation at $94{ }^{\circ} \mathrm{C}$ for $30 \mathrm{~s}$, annealing at $56^{\circ} \mathrm{C}$ for $30 \mathrm{~s}$ and extension at $72{ }^{\circ} \mathrm{C}$ for $30 \mathrm{~s}$, with a final extension at $72{ }^{\circ} \mathrm{C}$ for $10 \mathrm{~min}$. PCR products were examined on a $1 \%(\mathrm{w}: \mathrm{v})$ agarose gel with ethidium bromide staining in the presence of $100 \mathrm{bp}$ DNA ladder. PCR products were pooled and purified using QIA quick PCR purification Kit (Qiagen). DNA was quantified with Nano Drop (Thermo Scientific) and pooled before sequencing. Amplicons were sequenced on sequenced on Illumina MiSeq $2 \times 250$ bp platform in the laboratory of fungal biology, Institute of 
microbiology, The Czech Academy of Sciences, Prague, Czech Republic. Species area curve was generated in PCORD version 5 (McCune and Mefford, 2006). Curves were generated based on samples.

\subsection{BIOINFORMATICS}

Sequencing data was analysed in Seed software (Větrovský \& Baldrian, 2013), version 2.0.4. Following parameters were carried out: after rarefying the reads and demultiplexing of the samples based on their unique barcodes, removing low-quality sequences and sequences shorter than $40 \mathrm{bp}$, ITS sequences were extracted from the sequences, the contigs were chimaera-cleaned/clustered by the Usearch tool, version 8.1.1861, (Edgar \& Flyvbjerg, 2015) at the similarity level $97 \%$ and the most abundant sequences were compared while following blast tool version 2.2.26 + (Altschul et al., 2008). Sequencing similarity was matched against the sequences in GenBank database (environmental sequences, metagenomes and unidentified organisms excluded).

\subsection{STATISTICAL ANALYSIS}

To assess fungal community assemblage in argan plant species we carried out a nestedness analysis based on Nestedness Metric Based On Overlap And Decreasing Fill (NODF metric) (Almeida-Neto et al., 2008) implemented in Aninhado software (Guimaraesjr \& Guimaraes, 2006). We used present and absent data to compute NODF metric in Aninhado. Fungal OTUs present and absent data was permuted 1000 times and significance was assessed while following null models in Aninhado software. NODF values were inferred according to $p$-values of null models.

To discern pair wise fungal OTUs association in argan plant roots collected from sampling regions, nonrandom association between fungal OTUs was assessed. In order to remove a rare species bias, relationship between fungi having relative frequency of 7 was calculated. Unclassified/unidentified fungal species were also not kept in pairwise analysis as this can lead to false conclusion on OTU community. Presence/absence matrix was randomized and computed to get $\mathrm{C}$-scores and $p$-values respectively. Values were inferred while following fixedfixed null model. All the calculations were carried out in the Pairs software (Ulrich, 2008).

\section{RESULTS}

\subsection{FUNGAL COMMUNITY COMPOSITION}

Fungal community was diverse, as 1220 fungal OTUs including singletons were recorded. We removed singletons from our analysis, none the less it resulted in 586 OTUs belonging to 65 different genera. Ten most relatively frequent genera belonged to all three functional groups - endophytic, pathogenic and ectomycorrhizal fungi (Fig.1).

Some genera, such as Geopora, Sebacina, Knufia, Tomentella and Penicillim had high relative abundance in terms of sequence abundance reads (Fig.2).

Ascomycota was the most abundant phylum in all regions (461 reads) comparing to Basidiomycota (125 reads) $(\mathrm{p}=0.0001)$.

The number of reads of OTUs varies between the

\section{Occurrence of Fungal OTUs in frequency}

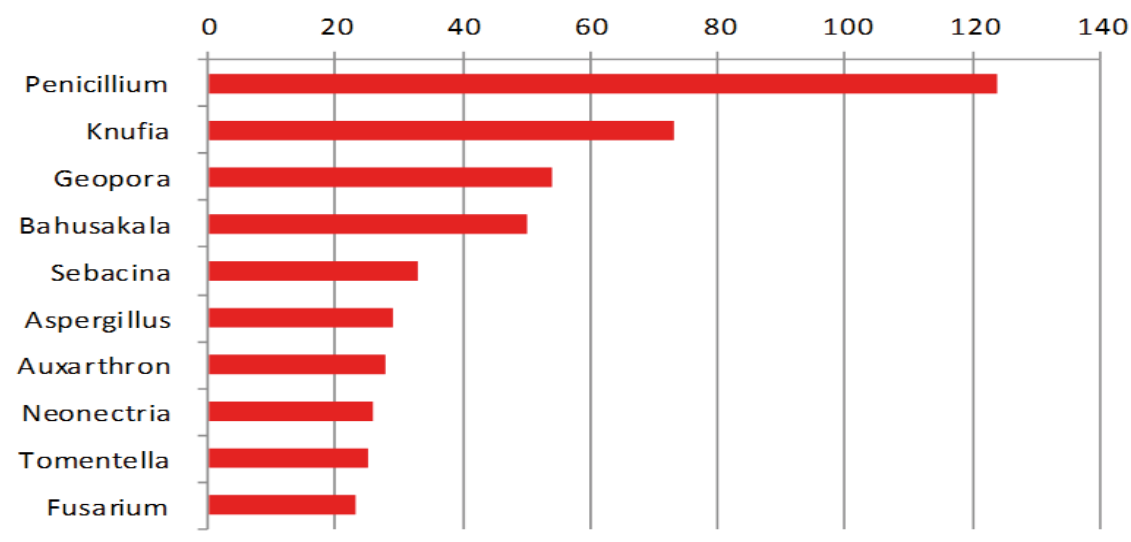

Figure 1: Relative frequency of different functional fungal genus 


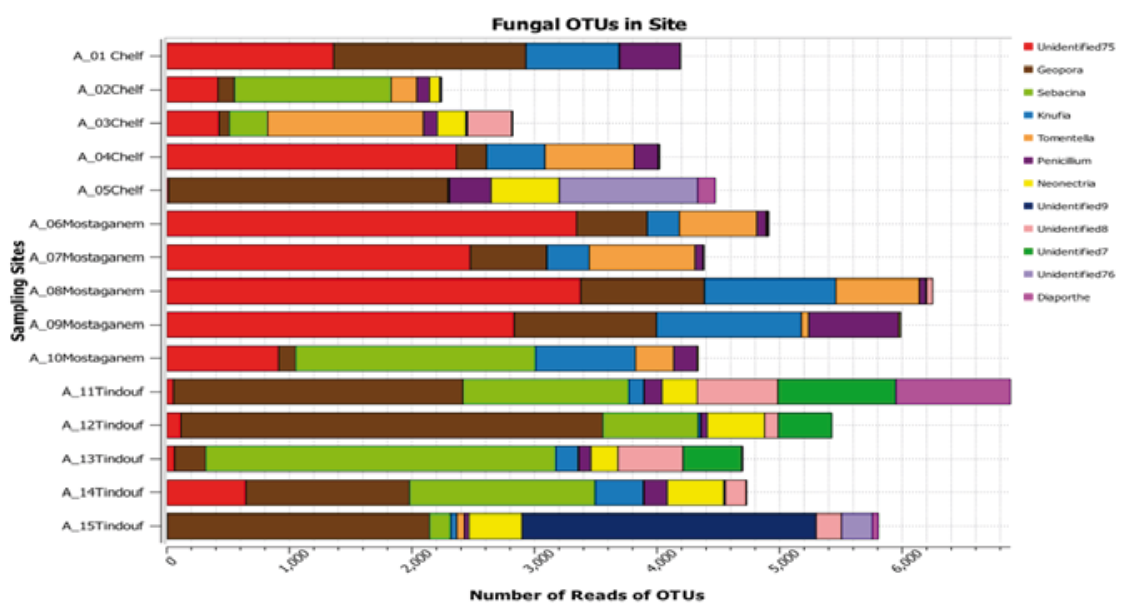

Figure 2: Relative abundance of fungal genus

three regions and from one tree to another in the same region. In fact, Mostaganem was the richest region with fungal community. The genus Neonectria was absent in all samples of Mostaganem region. (Figure 2). Sebacina was the most abundant genus in Tindouf and absent in all samples of Mostagenem, Geopora came in the second position in the same region. However the undefined fungi were the most important fungi in Chlef and Mostaganem $(\mathrm{p}=0.001)$.
Sample based curve captured maximum diversity for common fungal OTUs (Fig. 3a), and rarefaction revealed increase in OTU richness, whereas we did not obtain a plateau curve for rare fungal taxa (Figure 3a, Figure 3b).

\subsection{FUNGAL COMMUNITY ASSEMBLAGE/NEST- EDNESS ANALYSIS}

According to our expectations, we detected low lev-
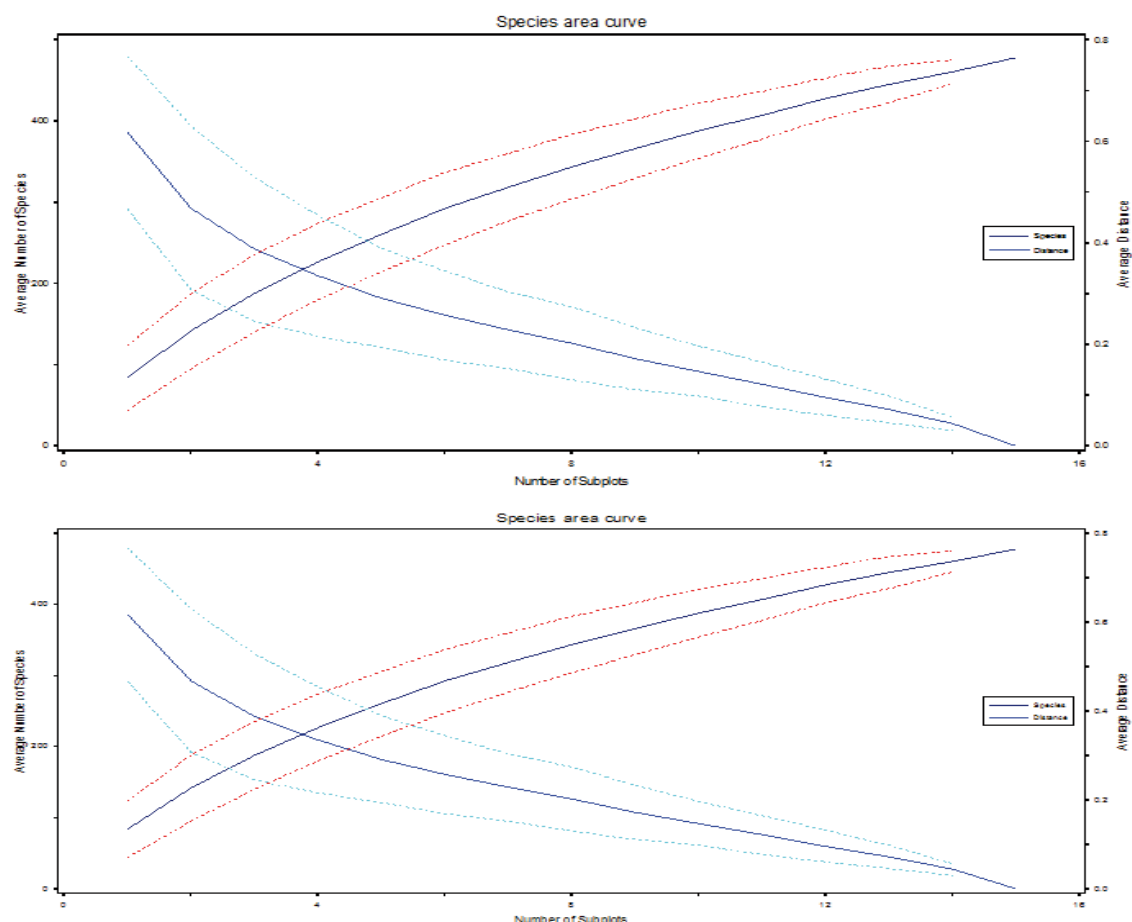

Figure 3a, b: Rarefaction curve for all fungal OTUs. a) Species area curve without singletons. b) Species area curve with singletons. $\mathrm{X}$-axis $=$ number of subplots and Y-axis $=$ OTUs and Sorenson distance of OTUs 
Table 2: Species pair results based on $\mathrm{Z}$ and $\mathrm{P}$ values

\begin{tabular}{llcc}
\hline Species 1 & Species 2 & Z -score & P-value \\
\hline Phomopsis sp. & Tricholoma sp. & 4.9 & $6 \times 10^{-7}$ \\
Tricholoma sp. & Pseudogymnoascus sp. & 4.9 & $6 \times 10^{-7}$ \\
Knufia sp.4 & Phomopsis sp. & 4.6 & $3.5 \times 10^{-6}$ \\
Tomentella sp. & Phomopsis sp. & 4.5 & $4.2 \times 10^{-6}$ \\
Pseudogymnoascus sp & Bahusakala sp. 2 & 4.4 & $8.7 \times 10^{-6}$ \\
Knufia sp.4 & Pseudogymnoascus sp. & 3.7 & $1.4 \times 10^{-4}$ \\
Knufia sp.4 & Diaporthe sp. & 3.7 & $2.0 \times 10^{-4}$ \\
Knufia sp.3 & Phomopsis sp. & 3.3 & $8.8 \times 10^{-4}$ \\
Tomentella sp. & Pseudogymnoascus sp. & 3.1 & $1.6 \times 10^{-3}$ \\
Tricholoma sp. & Embellisia sp. & 3.1 & $1.7 \times 10^{-3}$ \\
Pyrenochaeta sp. & Penicillium sp.6 & 2.9 & $3.2 \times 10^{-3}$ \\
Tricholoma sp. & Diaporthe sp. & $3.8 \times 10^{-3}$ \\
Knufia sp.3 & Diaporthe sp. & 2.8 & $4.8 \times 10^{-3}$ \\
Knufia sp.3 & Embellisia sp. & 2.8 & $5.9 \times 10^{-3}$ \\
Phomopsis sp. & Pseudogymnoascus sp. & 2.7 & $4.7 \times 10^{-2}$ \\
\hline
\end{tabular}

el of nestedness as revealed by analysis. NODF values for whole fungal community were significantly not higher than expected by chance $(\mathrm{NODF}=16, p=0.7)$.

\subsection{GENUS PAIR ANALYSIS}

19 species depicted significant non-random association and majority of species showed segregation pattern, while 5 species revealed positive co-occurrence (Table 2). Competitive interactions were predominant at phylum and subphylum level. Positive interactions between the fungi at same and different genera were observed (Table 2).

\section{DISCUSSION}

Using high throughput sequencing, we explored fungal communities in semi-arid region. Majority of fungal OTUs belonged to Ascomycota phylum. Culturing based study also revealed dominancy of Ascomycota fungi in desert covered by Artemisia herba-alba Asso and Zygophyllum dumosum Boiss. (Grishkan \& Nevo, 2010). Current results are also in line with study conducted in semi-arid areas. Based on high throughput sequencing technology (Wehner et al., 2014), highlighted abundance of Ascomycota phylum in semi-arid. Our results support notions that desert plant Argania spinosa harbour diverse fungal communities. We reported fungal OTUs representing different functional diversity such as mycorrhizal, endophytic and pathogens. It is not uncommon to report and document such functional diversity in semi-arid habitat. It has been well documented occurrence of mycorrhizal, endophytic and pathogens diversity in semi-arid (Porras-Alfaro et al., 2008). We highlighted dominancy of Ascomycota phylum and fungal OTUs such as Penicillium and Fusarium. Indeed, semiarid supports high endophytic fungal diversity, as strong evidences suggest prevalence and dominancy of Ascomycota, Penicillium and Fusarium (Gonzalez-Teuber et al., 2017) Fungal OTUs i.e. Geopora which are identified and characterized in present research could be compared with other habitats, as Geopora formed mycorrhizal association with Pinus species (Flores-Renteria et al., 2014), and samples collected in dry season revealed dominancy of Geopora genus fungi (Gordon \& Gehring, 2011). This shows adaptability and occurrence of Geopora in various environmental conditions argan plant supports high fungal diversity, as Basidiomycota members were also recorded. Usually Basidiomycetes fungi are found in relative moist habitat (Buee et al., 2009), therefore fungal diversity explored could be linked other habitats. Research carried out in secondary temperate forest documented occurrence of endophytic and ectomycorrhizal fungi in single host plant species (Frossard et al., 2015). Sebacina genus was among abundant fungal genus detected in argan root samples from Tindouf. There is strong evidence which supports ubiquitous nature of Sebacinales and such emerging evidences indicate ubiquitous occurrence 
of fungi in various habitats. Our results did not capture rare fungal diversity (Figure 3b). The plausible explanation for such absence of rare fungal diversity is overexploitation of argan plant species and overexploitation may stem local extinction of rare fungal taxa.

Fungal community depicted non-nested assemblage and on the contrary fungi revealed competitive interactions (Table 2). Current non nested findings also confirm that fungi have similar pattern as compare to fungi in forests. We found support for our hypothesis that fungi may lack nested pattern and it could also lead to conclusion that argan root do not support facilitative interactions. Similar results were documented by some other authors (Bahram et al., 2014; Roy-Bolduc et al., 2016). Since, argan plants are cultivated and thus under human management and grazing pressure (Charrouf \& Guillaume, 2009; Díaz-Barradas et al., 2010), we cannot exclude anthropogenic factors causing a non-nested assemblage of fungi. Another explanation is that host plants were under abiotic stress, which in turn may had generated non nested pattern.

Pair wise analysis mirrored segregation pattern between same and different functional fungal group. Several mechanisms are proposed to reveal such non-random occurrence pattern and competitive interactions between fungal OTUs could generate segregation pattern (Chen et al., 2000; Chilvers et al., 1987).

Competitive interactions between fungal OTUs in semi-arid have revealed that fungal communities were non-randomly structured in semi-arid. Our results are in line with (Wehner et al., 2014) who highlighted the abundance of Ascomycota phylum in semi-arid. We also showed that majority of fungal OTUs belonging to Ascomycota phylum had Z- scores -2 above 2 (Table2), showing statistical significance (Ulrich, 2008). Fungal pairs having endophytic and mycorrhizal mode of life style had high Z-scores, which indicated strong signal of competition between them. It is important to mention that previous studies focused on fungal groups and highlighted the prevalence of segregation patterns between ectomycorrhizal and endophytic fungi (Pickles et al., 2012; Saunders et al., 2010).

Positive interactions between same and different fungal OTUs suggested facilitative interactions between fungi. Facilitative interactions between fungi could be due to fact that fungi having similar functional requirements may occupy the same habitat which in turn could result in facilitative interactions. Species may sort according to shared requirements (Leibold et al., 2004), this may generate positive interactions between species. Given the fact, different functional genus in root occur due to different ecological and physiological requirements; henceforth there is high probability of positive interac- tions between fungi and facilitative interactions are well documented between different functional fungal groups (Wagg et al., 2008).

\section{CONCLUSIONS}

The present study is the first study to assess fungi associated with Argania spinosa roots growing in the arid and semi-arid climate. We revealed non nested assemblage pattern at community level, whereas pair wise association showed non-random pattern. Quite significant numbers of fungal OTUs were explored.

Future studies may carry out abundance-based data to assess pair wise association between fungi. We provide framework and initial study while using present-absent data to reveal non-random association of fungi in argan roots. Furthermore, inoculation experiments may be conducted to confirm facilitative and competitive interactions. Perhaps most striking feature of our research was high fungal diversity associated to single desert plant species.

\section{ACKNOWLEDGEMENT}

We would like to acknowledge Dr. Jan Jansa for providing the equipment and technical support for experiments involving sequencing. We also thank Professor Ahmed Aichouni, director of the laboratory of natural bio resources for the excellent laboratory facilities

\section{REFERENCE}

Austin, A. T., Yahdjian, L., Stark, J. M., Belnap, J., Porporato, A., Norton, U., Schaeffer, S. M. (2004). Water pulses and biogeochemical cycles in arid and semiarid ecosystems. [Research Support, Non-U.S. Gov't https://doi.org/10.1007/s00442004-1519-1

Bahram, M., Harend, H., \& Tedersoo, L. (2014). Network perspectives of ectomycorrhizal associations. Fungal Ecology, 7, 70-77. https://doi.org/10.1016/j.funeco.2013.10.003

Buee, M., Reich, M., Murat, C., Morin, E., Nilsson, R. H., Uroz, S., \& Martin, F. (2009). Pyrosequencing analyses of forest soils reveal an unexpectedly high fungal diversity. [Research Support, Non-U.S. Gov't]. New Phytol, 184(2), 449456. https://doi.org/10.1111/j.1469-8137.2009.03003.x

Charrouf, Z., \& Guillaume, D. (2009). Sustainable Development in Northern Africa: The Argan Forest Case. Sustainability, 1(4), 1012-1022. https://doi.org/10.3390/su1041012

Collins, S. L., Sinsabaugh, R. L., Crenshaw, C., Green, L., Porras-Alfaro, A., Stursova, M., \& Zeglin, L. H. (2008). Pulse dynamics and microbial processes in aridland ecosystems. 
Journal of Ecology, 96(3), 413-420. https://doi.org/10.1111/ j.1365-2745.2008.01362.x

Courty, P.-E., Buée, M., Diedhiou, A. G., Frey-Klett, P., Le Tacon, F., Rineau, F., Garbaye, J. (2010). The role of ectomycorrhizal communities in forest ecosystem processes: New perspectives and emerging concepts. Soil Biology and Biochemistry, 42(5), 679-698. https://doi.org/10.1016/j.soilbio.2009.12.006

Díaz-Barradas, M. C., Zunzunegui, M., Ain-Lhout, F., Jáuregui, J., Boutaleb, S., Álvarez-Cansino, L., \& Esquivias, M. P. (2010). Seasonal physiological responses of Argania spinosa tree from Mediterranean to semi-arid climate. Plant and Soil, 337(1-2), 217-231. https://doi.org/10.1007/s11104010-0518-8

Edgar, R. C., \& Flyvbjerg, H. (2015). Error filtering, pair assembly and error correction for next-generation sequencing reads. [Evaluation Studies]. Bioinformatics, 31(21), 34763482. https://doi.org/10.1093/bioinformatics/btv401

Finlay, R. D. (2008). Ecological aspects of mycorrhizal symbiosis: with special emphasis on the functional diversity of interactions involving the extraradical mycelium. [Research Support, Non-U.S. Gov't. https://doi.org/10.1093/jxb/ern059

Flores-Renteria, L., Lau, M. K., Lamit, L. J., \& Gehring, C. A. (2014). An elusive ectomycorrhizal fungus reveals itself: a new species of Geopora (Pyronemataceae) associated with Pinus edulis. [Research Support, Non-U.S. Gov't https://doi. org/10.3852/13-263

Fortuna Miguel, A., Stouffer Daniel, B., Olesen Jens, M., Jordano, P., Mouillot, D., Krasnov Boris, R., Bascompte, J. (2010). Nestedness versus modularity in ecological networks: two sides of the same coin? Journal of Animal Ecology, 79(4), 811-817. https://doi.org/10.1111/j.1365-2656.2010.01688.x

Frossard, A., Ramond, J.-B., Seely, M., \& Cowan, D. A. (2015). Water regime history drives responses of soil Namib Desert microbial communities to wetting events. Scientific Reports, 5, 12263. https://doi.org/10.1038/srep12263

Gonzalez-Teuber, M., Vilo, C., \& Bascunan-Godoy, L. (2017). Molecular characterization of endophytic fungi associated with the roots of Chenopodium quinoa inhabiting the Atacama Desert, Chile. Genom Data, 11, 109-112. https://doi. org/10.1016/j.gdata.2016.12.015

Gordon, G. J., \& Gehring, C. A. (2011). Molecular characterization of pezizalean ectomycorrhizas associated with pinyon pine during drought. [Research Support, Non-U.S. Gov't. https://doi.org/10.1007/s00572-010-0349-8

Research Support, U.S. Gov't, Non-P.H.S.]. Mycorrhiza, 21(5), 431-441. https://doi.org/10.1007/s00572-010-0349-8

Grishkan, I., \& Nevo, E. (2010). Spatiotemporal distribution of soil microfungi in the Makhtesh Ramon area, central Negev desert, Israel. Fungal Ecology, 3(4), 326-337. https://doi. org/10.1016/j.funeco.2010.01.003

Guimaraesjr, P., \& Guimaraes, P. (2006). Improving the analyses of nestedness for large sets of matrices. Environmental Modelling \& Software, 21(10), 1512-1513. https://doi. org/10.1016/j.envsoft.2006.04.002

Ihrmark, K., Bodeker, I. T., Cruz-Martinez, K., Friberg, H., Kubartova, A., Schenck, J., Lindahl, B. D. (2012). New primers to amplify the fungal ITS2 region--evaluation by 454 -sequencing of artificial and natural communities. [Research
Support, Non-U.S. Gov't]. FEMS Microbiol Ecol, 82(3), 666677. https://doi.org/10.1111/j.1574-6941.2012.01437.x

Kenny, L., \& De Zborowski, I. (2007). Atlas de l'arganier et de larganeraie. Rabat, Maroc: IAV Hassan II.

Leibold, M. A., Holyoak, M., Mouquet, N., Amarasekare, P., Chase, J. M., Hoopes, M. F., . . Gonzalez, A. (2004). The metacommunity concept: a framework for multi-scale community ecology. Ecology Letters, 7(7), 601-613. https:// doi.org/10.1111/j.1461-0248.2004.00608.x

Loro, M., Valero-Jiménez, C. A., Nozawa, S., \& Márquez, L. M. (2012). Diversity and composition of fungal endophytes in semiarid Northwest Venezuela. Journal of Arid Environments, 85, 46-55. https://doi.org/10.1016/j. jaridenv.2012.04.009

Martínez-García, L. B., Armas, C., Miranda, J. d. D., Padilla, F. M., \& Pugnaire, F. I. (2011). Shrubs influence arbuscular mycorrhizal fungi communities in a semi-arid environment. Soil Biology and Biochemistry, 43(3), 682-689. https:// doi.org/10.1016/j.soilbio.2010.12.006

Pickles, B. J., Genney, D. R., Anderson, I. C., \& Alexander, I. J. (2012). Spatial analysis of ectomycorrhizal fungi reveals that root tip communities are structured by competitive interactions. [Research Support, Non-U.S. Gov't]. Mol Ecol, 21(20), 5110-5123. https://doi.org/10.1111/j.1365294X.2012.05739.x

Porras-Alfaro, A., Herrera, J., Sinsabaugh, R. L., Odenbach, K. J., Lowrey, T., \& Natvig, D. O. (2008). Novel root fungal consortium associated with a dominant desert grass. [Research Support, U.S. Gov't, Non-P.H.S.]. Appl Environ Microbiol, 74(9), 2805-2813. https://doi.org/10.1128/AEM.02769-07

Roy-Bolduc, A., Laliberte, E., \& Hijri, M. (2016). High richness of ectomycorrhizal fungi and low host specificity in a coastal sand dune ecosystem revealed by network analysis. Ecol Evol, 6(1), 349-362. https://doi.org/10.1002/ece3.1881

Saunders, M., Glenn, A. E., \& Kohn, L. M. (2010). Exploring the evolutionary ecology of fungal endophytes in agricultural systems: using functional traits to reveal mechanisms in community processes. Evol Appl, 3(5-6), 525-537. https:// doi.org/10.1111/j.1752-4571.2010.00141.x

Sellal, Z. (2016). Arbuscular Mycorrhizal fungi species associated with rhizosphere of Argania spinosa (L.) Skeels in Morocco. International Journal of Pure \& Applied Bioscience, 4(1), 82-99. https://doi.org/10.18782/2320-7051.2201

Smith, S. E., \& Read, D. (2008). 1 - The symbionts forming arbuscular mycorrhizas Mycorrhizal Symbiosis (Third Edition) (pp. 13-41). London: Academic Press. https://doi. org/10.1016/B978-012370526-6.50003-9

Treseder, K. K. (2004). A meta-analysis of mycorrhizal responses to nitrogen, phosphorus, and atmospheric CO2 in field studies. New Phytologist, 164(2), 347-355. https://doi. org/10.1111/j.1469-8137.2004.01159.x

Ulrich, W. (2008). Pairs - a FORTRAN program for studying pair wise species associations in ecological matrices [8]. Pairs.

Ulrich, W., Almeida-Neto, M., \& Gotelli, N. J. (2009). A consumer's guide to nestedness analysis. Oikos, 118(1), 3-17. https://doi.org/10.1111/j.1600-0706.2008.17053.x

Větrovský, T., \& Baldrian, P. (2013). Analysis of soil fungal communities by amplicon pyrosequencing: current approaches to data analysis and the introduction of the pipeline SEED. 
Biology and Fertility of Soils, 49(8), 1027-1037. https://doi. org/10.1007/s00374-013-0801-y

Wagg, C., Pautler, M., Massicotte, H. B., \& Peterson, R. L. (2008). The co-occurrence of ectomycorrhizal, arbuscular mycorrhizal, and dark septate fungi in seedlings of four members of the Pinaceae. [Research Support, Non-U.S. Gov't]. $M y$ corrhiza, 18(2), 103-110. https://doi.org/10.1007/s00572007-0157-y

Wehner, J., Powell, J. R., Muller, L. A. H., Caruso, T., Veresoglou, S. D., Hempel, S., . . van der Heijden, M. (2014). Determinants of root-associated fungal communities within Asteraceae in a semi-arid grassland. Journal of Ecology, 102(2), 425-436. https://doi.org/10.1111/1365-2745.12197
White, T. J., Bruns, T., Lee, S., \& Taylor, J. (1990). Amplification and direct sequencing of fungal ribosomal RNA genes for phylogenetique. In A. Press (Ed.), PCR protocols (pp. 315). San Diego: Academic Press. https://doi.org/10.1016/B9780-12-372180-8.50042-1

Zhang, T., Jia, R.-L., \& Yu, L.-Y. (2016). Diversity and distribution of soil fungal communities associated with biological soil crusts in the southeastern Tengger Desert (China) as revealed by 454 pyrosequencing. Fungal Ecology, 23, 156163. https://doi.org/10.1016/j.funeco.2016.08.004 